\title{
Potential benefits of colostrum in gastrointestinal diseases
}

\section{Laura Menchetti ${ }^{1}$, Giovanna Traina ${ }^{2}$, Giovanni Tomasello ${ }^{3,4}$, Patrizia Casagrande-Proietti ${ }^{1}$, Leonardo Leonardi ${ }^{1}$, Olimpia Barbato ${ }^{1}$, Gabriele Brecchia ${ }^{1}$}

${ }^{1}$ Department of Veterinary Medicine, University of Perugia, via S. Costanzo 4, Perugia, Italy, ${ }^{2}$ Department of Pharmaceutical Sciences, University of Perugia, Via S. Costanzo, Perugia, Italy, ${ }^{3}$ Euro-Mediterranean Institute of Science and Technology (IEMEST), Via E. Amari 123, Palermo, Italy, ${ }^{4}$ DICHIRONS Department, University of Palermo, Via L. Giuffre 5, Palermo, Italy

\section{TABLE OF CONTENTS}

1. Abstract

2. Introduction

3. Quality of colostrum

4. Constituents and their functions

4.1. Anti-microbial and immune-stimulating factors

4.1.1. Immunoglobulins (Igs)

4.1.2. Lactoferrin $(L f)$

4.1.3. Lysozyme

4.1.4. Anti-oxidants

4.1.5. Nucleotides/nucleosides

4.1.6. Gangliosides

4.1.7. Oligopolysaccharides and glycolconjugate sugars

4.1.8. Proline rich polypeptide or colostrinin (CLN)

4.1.9. Cytokines

4.1.10. Leukocytes

4.2. Growth factors

4.2.1. Insulin-like growth factors I and II (IGF-I and IGF-II)

4.2.2. Epidermal growth factor (EGF)

4.2.3. Transforming growth factor- $\alpha$ (TGF- $\alpha)$

4.2.4. Transforming growth factor- $\beta$ (TGF- $\beta$ )

4.2.5. Platelet-derived growth factor (PDGF)

4.2.6. Vascular endothelial growth factor (VEGF)

5. Clinical applications

5.1. Acute infectious diarrhoea

5.2. Helicobacter spp infections

5.3. Drug-induced diarrhoea

5.3.1. Antibiotics

5.3.2. Chemotherapy

5.3.3. Non steroidal anti-inflammatory drugs (NSAIDs)

5.4. Immunodeficiency diarrhoea

5.5. Inflammatory bowel disease (IBD)

5.6. Necrotizing enterocolitis (NEC)

5.7. Short bowel syndrome (SBS)

5.8. Surgery

5.9. Side effects and contraindications

6. Conclusion

7. Acknowledgements

8. References

\section{ABSTRACT}

This paper reviews the composition of colostrum and the potential preventive and therapeutic use of this "first milk" for treating various gastrointestinal disorders in humans. Colostrum is a complex biological liquid that is richer in antimicrobial peptides, immune-regulating compounds and growth factors than the subsequent 
mature milk. The main functions of colostrum are to provide essential nutritional components, strengthen the natural defense system, modulate immune response, balance intestinal microbiota and enhance the growth and repair of several tissues. Several studies and clinical trials carried out both in vitro and in vivo on humans and animals suggest the clinical benefits of bovine colostrum (BC) supplementation in gastro-intestinal diseases. Despite the encouraging results, further well-designed studies are required in order to confirm these effects, the dose and duration of treatment. Colostrum is safe since there are no contraindications regarding high dose levels and few side effects of clinical relevance have been reported. In conclusion, in the near future, colostrumbased supplements may play a complementary role to synthetic drugs in the prevention and treatment of various gastrointestinal disorders.

\section{INTRODUCTION}

Colostrum is a biological fluid produced by the mammary gland after parturition, before it gradually loses its initial characteristics and to becomes mature milk. This secretion is fundamental for the survival of mammal offspring, especially for ungulates (1). Colostrum provides nutrition of newborns, enhances protection against pathogens, promotes the development of immune system and ensures the growth, maturation and repair of several tissues $(2,3)$. Several studies have extensively analysed the composition of bovine, goat and human colostrum highlighting the presence of at least ninety different biologically active substances essential for specific functions (4). The bioactive components of colostrum include: i) anti-microbial factors, ii) immunestimulating peptides and iii) growth factors (5). Antimicrobial factors provide passive immunity and protect against infections, especially during the first weeks of life. The anti-microbial activity of colostrum can be direct on pathogen agents or indirect by stimulating the growth of a healthy intestinal microbiota rich in Bifidobacteria and Lactobacilli $(6,7)$. Colostrum provides signals to the immune system by inducing tolerance to food and noninvasive antigens, thus avoiding the onset of an abnormal immune response while promoting its maturation and an adequate immune response against pathogens at the same time (8). Some components are able to promote the maturation and modulation of the immune system either directly as colostrinin, cytokines and lactoferrin, $\beta$-lactoglobuline, $\alpha$-lactalbumin and glycomacropeptide or indirectly as oligosaccharides, gangliosides and nucleosides that favour the development of beneficial bacteria species (2,3,9). Furthermore, colostrum contains growth factors that play important roles in the development, maturation and repair of various tissues (10). In recent decades, BC have been used for the prevention and treatment of a variety of human and animal diseases, especially but not only of the gastrointestinal system $(11,12)$. The aim of this review is to discuss the specific properties of some of the bioactive components of colostrum and to assess the potential clinical uses of colostrum in the prevention and treatment of various gastrointestinal disorders. This review is divided into three sections: 1) quality of colostrum; 2) constituents of colostrum and their functions; 3 ) clinical uses.

\section{QUALITY OF COLOSTRUM}

It is important to note that $\mathrm{BC}$ composition can vary and therefore product quality must be carefully evaluated when it is used as a supplement for humans and animals. The quality of $\mathrm{BC}$ depends on various factors: species, breed, farm management, collection period, number of parturitions and kids, animal health and processing practices. All these factors can influence the quality of $\mathrm{BC}$ by affecting the amounts of nutritional and biological active constituents, yet the most important factors affecting quality are probably collection period and processing procedures $(13,14)$. In terms of composition, the best quality $\mathrm{BC}$ is produced during the first $24-48$ hours after parturition. In fact, the levels of several bioactive components decrease in time-dependent manner (15). $\mathrm{BC}$ products should be manufactured in technologically advanced facilities using low-heat pasteurization and low-pressure processing procedures in order to avoid the denaturation of components especially those from protein nature (16). Finally, BC for human and animal use should be accompanied by a certificate attesting its quality, efficacy and safety e.g. absence of drug residues, environmental contaminants and contagious infectious agents. At present there is no standard composition that clearly defines the $\mathrm{BC}$ to be used as a dietary supplement in human and animals.

\section{CONSTITUENTS AND THEIR FUNCTIONS}

\subsection{Anti-microbial and immune-stimulating factors}

Are represented by compounds of various natures that, which provide passive immunity, protect the host against the pathogenic agents and can also modulate the immune system both directly and indirectly thus favouring the growth of beneficial bacteria. Immunoglobulins, lactoferrin, lactoperoxidase, lysozyme, $\alpha$-lactalbumin and peptides derived from caseins such as glycomacropeptide (GMP) and whey proteins show high antimicrobial activity. Oligosaccharides, gangliosides and nucleosides provide protection against pathogens by acting as "false receptors" of intestinal cells. Moreover, they induce the proliferation of bifidobacteria and lactobacilli that not only inhibit the proliferation of the pathogens modulating the intestinal environment but also stimulate the immune system. Other components such as lactoferrin, colostrinin (CLN), cytokines and leucocytes have immune-modulatory functions. 


\subsubsection{Immunoglobulins (Igs)}

Concentrations in colostrum are very high and provide passive immunity to newborns during the development of their own immune systems but can also be useful for providing adults with protection against infection $(17,18)$. Colostrum contains five classes of Igs: $\lg A, \lg G, \lg D, \lg E$, $\lg M$ that prove to be effective in defending the body against bacteria, virus, parasites and fungi (19). There is a rapid decrease in the Igs concentration levels of the milkings in the days following parturition (1). By following specific vaccination protocols to cows during pregnancy, it is possible to increase the lgs levels of colostrum thus producing hyperimmune colostrum that can be used against specific pathogens (20).

\subsubsection{Lactoferrin (Lf)}

Is a multifunctional iron-binding glycoprotein present in several exocrine fluids including colostrum. Lf concentration differs among species and rapidly decreases with subsequent milkings (21). The biological activities of Lf include anti-infective, anti-oxidant, proliferative and immunemodulatory actions (22). Lf is directly effective against several bacteria, virus, fungi and protozoa species but could also have the indirect effect of modulating intestinal microbiota $(23,24)$. Moreover, Lf increases the proliferation and differentiation of intestinal epithelial cells (25). Lf influences the immune functions such as cytokine production, cytotoxicity, proliferation, maturation, migration and activation of macrophages, granulocytes, natural killer and $T$ and $B$ cells by binding its specific receptor (22). In some conditions, Lf proves to have pro-inflammatory properties that induce macrophage activation (22).

\subsubsection{Lysozyme}

Is an enzyme that has anti-microbial action on gram negative and positive bacteria thanks to its ability to split the peptidoglycan layer of the bacterial cell wall thus causing the lysis of infectious agents (26).

\subsubsection{Anti-oxidants}

Colostrum contains several compounds with both pro and anti-oxidant effect depending on physiological status (27). The compounds that are able to counteract the action of reactive oxygen species are superoxide dismutase, catalase, glutathione peroxidise, vitamin $A, E$ and $C$, ceruloplasmin, caseins and minerals as selenium, copper and zinc (28). Colostrum can be also considered to be a source of reactive oxygen species, since it presents macromolecules susceptible to peroxide processes as well as containing reactive oxygen species-generating systems such as xanthine oxidase and lactoperoxidase whose activities help to eliminate infectious agents (27).

\subsubsection{Nucleotides/nucleosides}

Are important as metabolites but also because they maintain the integrity of intestinal mucosa and influence the type of commensal flora as well as the proliferative action of growth factors $(29,30)$.

\subsubsection{Gangliosides}

In colostrum and milk are associated with the membrane of fat globules at various concentrations depending on species (31). They are involved in various fundamental cellular functions and in immune response but also act as receptors for various bacteria and toxins. Gangliosides, in particular disialoganglioside 3 (GD3) are involved in the proliferation, maturation and activation of lymphocites, dendritic cells, in cytokine production and intestinal IgA secretion thus suggesting an involvement in immune response (32). GD3 can also affect the development of several organs including the digestive and nervous systems. Monosialoganglioside 3 (GM3) is involved in the defensive mechanisms of the host since they act as "false" receptors for toxins and adhesins of pathogens bacteria (33). Gangliosides may also stimulate the proliferation of useful microbiota such as bifidobacteria and therefore participate indirectly in host defensive mechanisms (34).

\subsubsection{Oligopolysaccharides and glycolconjugate sugars}

Colostrum contains many sugars such as glycolipids, glycoproteins, cellulose, glycosaminoglycan and mucin, in addition to lactose which is the main sugar $(35,36)$. The soluble sugars of colostrum prevent the binding of bacteria and viruses to the intestinal cells by acting as "false" receptors (37). Some sugars such as fructo-oligosaccharides and galacto-oligosaccharides act as prebiotics in order to promote the growth and maintenance of healthy intestinal microbiota rich in Bifidobacteria and Lactobacilli (38). This beneficial bacteria produces several substances during its metabolism that inhibit the growth of harmful bacteria but also butyric acid which is used by intestinal epithelial cells (39). Furthermore, some Bifidobacteria and Lactobacilli strains can inhibit inflammatory responses in intestinal epithelial and immune cells (38).

\subsubsection{Proline rich polypeptide or colostrinin (CLN)}

The colostrum of several mammalian species is rich in CLN yet the largest amounts are found in bovine and human colostrum (40). CLN consists in several peptides that contain an unusually high portion of the amino acid proline and derive from the proteolysis of milk $\beta$-casein. Its biological activity is based on the action of more than one component and therefore poor activity levels are observed in the case of single components (41). CLN regulates the secretion of cytokines affecting both inflammatory and immune response. CLN is an intercellular signalling molecule that is able to modulate the immune system by regulating the proliferation and differentiation of immune cells both in vitro and in vivo (40). It stimulates weak or unreactive immune systems but can also restore the 
balance of immune functions when the immune system is hyperactive as in the case of autoimmune diseases or allergies $(42,43)$. CLN also plays an anti-oxidant role by reducing the levels of intracellular reactive oxygen species (ROS) and nitric oxide (NO) suggesting that it is able to control inflammatory response and those in which ROS are implicated in the pathogenesis (44). CLN has proved to have powerful immunomodulatory and neuroprotective properties that suppress chronic microglial cell activation and prevent the formation and increase the disruption of $\beta$-amyloid peptides (45). CLN induces the growth of neurons by modulating the expression of the genes responsible for the proliferation, differentiation and regeneration of cells in the nervous system and improves cognitive function in mammals $(46,47)$.

\subsubsection{Cytokines}

Are proteins, peptides or glycoproteins secreted by specific cells of the immune system which are essential for cellular communication (48). Cytokines are produced in the mammary gland and then released in colostrum. Colostrum contains numerous cytokines, in particular with anti-inflammatory activity that can regulate the development of the neonate immune system, and control inflammatory response and the production of antibodies $(49,50)$. They act in combination with other defensive components of colostrum such as Igs, lactoferrin and lactoperoxidase (51).

\subsubsection{Leukocytes}

Colostrum contains macrophages, lymphocytes and neutrophils that destroy the pathogens and parasites via phagocytosis (52). Furthermore, these immune cells modulating cytokine production can influence the development and the activity of the immune system of neonates (53).

\subsection{Growth factors}

Colostrum contains several growth factors that modulate the growth, maturation, function and repair of bone, muscle, nervous, connective, cartilage, skin tissues and particularly the gastro-intestinal mucosa (10).

\subsubsection{Insulin-like growth factors I and II (IGF-I and IGF-II)}

Also known as somatomedins are synthesized in the liver under the influence of the $\mathrm{GH}$ hormone and their receptors are found in the cells of various tissues, including the tissues of the gastro-intestinal tract (54). Somatomedins are carried in the blood by 6 types of proteins and promote the proliferation and differentiation of tissues as well as anabolic action by interacting with specific receptors (55). IGF-I is associated with cell proliferation in the crypts while IGF-II controls the mechanism of cell differentiation of intestinal epithelial cells (56).

\subsubsection{Epidermal growth factor (EGF) \\ Is a peptide present in colostrum and its} functions differ in neonates and adults. The EGF receptor is located in the basolateral membrane of the enterocyte and this suggests that it acts as readily available peptide surveillance for repairing injury sites in adults (57). In neonates, the growth factor can cross the intestinal barrier and binds to the receptor stimulating cellular growth (58). EGF may also prevent bacterial translocation in the gut and stimulates gut immunity (59).

\subsubsection{Transforming growth factor- $\alpha$ (TGF- $\alpha$ )}

Is a peptide present in colostrum and milk but it is also synthesized in the mucosa of the gastro-intestinal tract (60). Systemic administration of TGF- $\alpha$ stimulates the secretion of mucin, cell growth, wound healing and inhibits acid secretion. Its physiological role is cellular differentiation and migration rather than proliferation and it is useful for repairing and maintaining the integrity of intestinal epithelium (61).

\subsubsection{Transforming growth factor- $\beta$ (TGF- $\beta$ ) Includes 5 isoforms of TGF- $\beta$ and their} binding site is the surface of the intestine (61). TGF- $\beta$ inhibits cell proliferation, is a powerful chemo-attraction for neutrophils and plays a role in the repair process by stimulating the migration of epithelial cells on the denuded area to re-establish epithelial continuity (62). It regulates the inflammatory and immune response in the intestinal mucosa by intervening in T helper lymphocytes differentiation and IgA production $(62,63)$.

\subsubsection{Platelet-derived growth factor (PDGF)}

Is a peptide obtained from platelets but is also produced by macrophages. PDGF is a potent mitogen for fibroblasts and facilitates the healing of ulcers (64).

\subsubsection{Vascular endothelial growth factor (VEGF) Is a peptide with potent angiogenic and mitogenic activity, which acts on vascular permeability (65). VEGF is present in colostrum and its receptor is located on the apical membranes of epithelial cells (66). These findings suggest a role for VEGF in digestive system physiology.}

\section{CLINICAL APPLICATIONS}

This section of the review reports the effects of colostrum on various disorders of the gastro-intestinal tract, in particular those accompanied by inflammatory processes, by referring to relevant in vitro and in vivo studies (67-69). It is also important to note that some of these studies were of poor methodological quality therefore the results could not be confirmed by other researchers. $\mathrm{BC}$ may provide insights into the prevention and treatment of gastro-intestinal disorders, but further studies are required before it can be used for human beings.

\subsection{Acute infectious diarrhoea}

Is a common problem in developing countries and for travellers who visit them. It is usually caused by bacterial, viral, or parasitic infection. It could be 
associated with inflammation, intestinal damage, increased intestinal permeability, bacterial translocation and multiple organ dysfunctions. Supportive therapy (appropriate diet, fluid therapy) should be considered for all patients suffering from diarrhoea, while antimicrobials are not recommended as enteropathogens are often associated with self-limiting diarrhoea. Numerous in vivo and in vitro studies have shown that $\mathrm{BC}$ is beneficial in the prevention and treatment of infective gastroenteritis for various animal species, including human beings (70-74). Colostrum and hyperimmune colostrum are effective against a wide variety of intestinal pathogens. Rotavirus is a common cause of viral gastroenteritis in infants and children for which there is not currently an effective vaccine, therefore a new strategy is required in order to reduce the duration and severity of clinical signs. The treatment of rotavirus-infected infants with hyperimmune $\mathrm{BC}$ reduced the duration of diarrhoea and excretion of virus, and the passive immunization of healthy infants with colostrum antibodies reduced the incidence and duration of diarrhoea compared to the placebo group (75-77). On the contrary, the treatment of hospitalized infants with hyperimmune $\mathrm{BC}$ did not reduce the duration and severity of diarrhoea (78). In a mouse animal model, multiple administration of $\mathrm{BC}$ before the inoculation of rotavirus resulted in earlier recovery from diarrheal symptoms (74). Enterotoxigenic Escherichia coli commonly causes diarrhoea in travelers and infants in developing countries. Several studies have proved the effectiveness of BC in preventing infection caused by $E$. coli (79-83). Otto et al., reported that a tablet formulation of hyperimmune $\mathrm{BC}$ was more effective than placebo in protecting human volunteers against the development of diarrhoea caused by the bacteria (80). In a randomized, double-blind, controlled field trial, hyperimmune BC-fed infants showed a reduction in incidence and duration of diarrhoea compared to formula-fed infants (84). Two clinical studies showed that the administration of anti-E. coli lgG obtained from BC before oral challenge with enterotoxigenic Escherichia coli was effective in preventing clinical diarrhoea $(85,86)$. Clostridium difficile is a bacterium that has proved to be the main cause of infectious diarrhoea. In gnotobiotic piglets with Clostridium difficile infection the administration of hyperimmune $\mathrm{BC}$ reduced the development of diarrhoea and colitis, in respect to control animals (20). In another study, hamsters treated prophylactically with hyperimmune $\mathrm{BC}$ were protected against $C$. difficile infection (87). In humans, anti-C. difficile hyperimmune $\mathrm{BC}$ was as effective as metronidazole in the prevention of bacterial infection (88). Finally, in vitro studies showed that hyperimmune $B C$ inhibits the adhesion of $C$. difficile to enterocyte-like caco-2 cells and was effective in neutralizing $A$ and $B$ toxins in cultured tissue $(87,89)$. Protozoa such as Criptospridium parvum or Entamoeba histolytica and Candida albicans fungi can also cause acute diarrhoea (90-93). Cryptosporidium species generally cause chronic diarrhoea in immunocompromised individuals. Oral administration of hyperimmune $\mathrm{BC}$ in immunocompromised children and adults proved to be effective for treating cryptosporidiosis and in the prevention of cryptosporidiosis in healthy volunteers when administered before challenge with C. parvum spores $(91,92)$. Immunoglobulins concentrate obtained from hyperimmune $\mathrm{BC}$, was effective in treating diarrhoea in C. parvum-infected AIDS patients (93). The prophylactic and therapeutic effect of colostrum may be due to several compounds which can act in the various phases of the infective disease: they can eliminate the pathogens, improve the intestinal barrier functions, normalize host intestinal flora, inhibit bacterial translocation and modulate immune response by reducing the severity of inflammation (81, 94-100).

\subsection{Helicobacter spp infections}

Although Helicobacter species are commonly found in healthy humans and pets, this bacterium is found in $100 \%$ of the subjects presenting symptoms of chronic vomiting and malnutrition. $H$. pylori is the main species found in humans, $H$. Bizzozeronii is found in dogs while $H$. felis and $H$. heilmannii are the species most commonly found in cats (101). Helicobacter infections can cause inflammation of the tissues lining the stomach and duodenum thus causing acute and chronic gastritis, duodenitis, and peptic ulcers. The clinical signs of the infection are represented by nausea, vomiting, diarrhoea, abdominal pain, lack of appetite or anorexia and weight loss. Therapy consists in a combination of two antibiotics and an antisecretory drug, such as a protonpump inhibitor or a H2-receptor antagonist, which shows a low percentage of eradication of the bacteria and various side effects such as diarrhoea due to intestinal dysbiosis and the selection of Clostridium difficile (102). Several in vitro and in vivo studies performed in mice have proved the effectiveness of $\mathrm{BC}$ in preventing and treating the Helicobacter infection $(103,104)$. The beneficial effect of colostrum may have inhibited the invasive capacity of pathogen bacteria, modulation of immune response and favoured mucosal repair as highlighted by various in vitro studies $(10,68,105-108)$. Daily administration of hyperimmune colostrum to adults or children for 4 weeks reduced the severity of clinical signs and inflammation but only eradicated the bacteria in few patients $(109,110)$. However, the administration of hyperimmune colostrum to adult $H$. pylori-infected patients had no significant effect on the urea breath test or histological $H$. pylori count (111). In another study performed in $\mathrm{H}$. pylori-positive infants colostrum was not able to eradicate $H$. pylori as assessed by the urea breath test (112). Further well-designed studies are required in order to evaluate the effectiveness of $\mathrm{BC}$ in preventing and treating the Helicobacter infection.

\subsection{Drug-induced diarrhoea}

The most common drugs that cause diarrhoea are antibiotics, chemotherapy drugs and non-steroidal anti-inflammatory drugs (NSAIDs). 


\subsubsection{Antibiotics}

are commonly used for treating several infectious diseases and can benefit both animal and human health. Occasionally, oral antibiotics can cause unwanted adverse effects like diarrhoea due to changes in intestinal microbiota. Dysbiosis can favour the selection of opportunistic or pathogenic bacteria such as Clostridium difficile, which is a frequent complication of long-term, broad-spectrum antibiotic therapy (20). Furthermore, microbial imbalance can also cause changes in intestinal homeostasis with increased permeability, bacterial translocation, abnormal immune response, and strong inflammatory reaction can occur (97-100). Colostrum and hyperimmune BC administration at the start of antibiotic treatment may reduce the risk of antibioticassociated diarrhoea; selection of Clostridium difficile and it may also have a positive effect in regulating the immune system $(2,6,12,20,51,70,113)$. Moreover unlike conventional antimicrobials, BC favours the growth of beneficial bacterial populations by avoiding antibioticresistant organisms $(20,95)$.

\subsubsection{Chemotherapy}

Cancer is one of the most common diseases of this century effecting both humans and animals. Most tumours are treated with chemotherapy. Chemotherapic agents have strong side effects on rapidly growing and self-renewing tissues such as intestinal and oral mucosa, bone marrow and hair follicles. Chemotherapeutic agents cause "intestinal mucositis", a condition characterized by apoptosis and loss of cellular proliferation in the intestinal epithelium, resulting in crypt loss, villus atrophy and ulcerations that increase gut permeability, bacteria translocation and bleeding (114). Chemotherapy also induces immunosuppression increasing the risk of opportunistic infections and inflammations due to alterations in gut microbiota $(115,116)$. One of the side effects of chemotherapy is "oral mucositis" causing pain and inflammation to the lining of the mouth (114). To date, there are no available drugs that can prevent mucositis. If severe lesions occur in the gastro-intestinal tract, it may be advisable to reduce the dose or discontinue treatment that consequently reduces the effectiveness of the chemotherapy. New strategies for protecting tissues and stimulating their recovery may increase the chemotherapy dose and the duration of the treatment $(117,118)$. The administration of colostrum reduced gut toxicity during myeloablative chemotherapy in piglets (119). Growth factors included in BC in high concentrations as TGF- $\beta$, EGF and IGF-I aided the recovery of rat intestinal mucosa damaged by methotrexate and improved chemotherapyinduced mucositis $(120,121)$. Satisfactory results were not obtained in all of the studies, EGF only had a minor beneficial effect in reducing oral ulcerations in patients undergoing chemotherapy (122). Colostrum contains antimicrobial and growth factors that, by fighting infection and stimulating cellular proliferation, may be used as adjuvant therapy for treating the intestinal mucosa in combination with or following chemotherapy in order to reduce the detrimental effects of chemotherapic drugs in tissues $(10,12,68,94,123,124)$. Finally, BC can reduce body weight loss associated with the treatment $(125,126)$.

\subsubsection{Non steroidal anti-inflammatory drugs (NSAIDs)}

Are among the drugs most commonly used worldwide due to their anti-inflammatory, analgesic and antipyretic effects both in human and in animals (127). However, NSAIDs are associated with a broad spectrum of side effects, mainly in the upper gastrointestinal tract. These drugs cause gastro-intestinal damage by reducing the mucosal gastric barrier and blood flow and stimulating apoptosis with predisposition to inflammation and mucosal ulcerations $(109,128)$. NSAIDs can also alter the microbiota thus causing the overgrowth of Gram negative and anaerobic bacteria that results in the over secretion of pro-inflammatory cytokines and bacterial translocation $(129,130)$. Current therapeutic options include coadministration of acid suppressants, prostaglandin analogues and relatively selective cyclooxygenase II inhibitors. However, none of these options are optimal and new approaches are required. It is likely that many of the mechanisms caused by NSAIDs to determine their side effects may be counteracted by the biologically active components present in BC which work in an additive or synergistic way $(10,68)$. BC contains various growth factors that can stimulate the healing of ulcers as well as other compounds that can control inflammatory response, infections and epithelial barrier functions and are useful in the event of gastrointestinal injuries $(68,131-133)$. Various models have been used to evaluate the effect of colostrum in reducing intestinal lesions and stimulating their repair $(64,124,134-136)$. With regard to indomethacin-induced enteropathy, both prefeeding and postfeeding mice with $\mathrm{BC}$ facilitated the growth of intestinal villi, thus indicating preventive and healing effects (124). Colostrum-based supplements reduced gut damage and bacterial translocation in rats caused by diclofenac (134). In a rat model of gastric injury and a mouse model of intestinal injury, $\mathrm{BC}$ reduced the severity of the lesions caused by the administration of indomethacin (136). Furthermore, an in vitro study showed that $\mathrm{BC}$ increased proliferation and cell migration of RIE-1 and HT-29 cells (136). Colostrum reduces gastric and intestinal lesions, permeability of the intestinal wall, bacterial translocation and shortening of villi $(124,137,138)$. In human volunteers, the co-administration of $\mathrm{BC}$ and indomethacin reduced gut permeability in respect to the control group that only received the anti-inflammatory drug (137). Kim et al., showed that the combined administration of BC and diclofenac in rats reduced the increase in intestinal permeability, changes of microbiota and villous damage caused by diclofenac (138). BC may prove to be useful for the prevention and treatment of intestinal ulcerative conditions. 


\subsection{Immunodeficiency diarrhoea}

Immunodeficiency is a state in which the ability of immune system to fight infections is compromised or entirely absent and immunocompromised subjects may be particularly vulnerable to opportunistic infections. Most infectious causes of immunodeficiency are due to viral infections (HIV in humans) that attack the immune system and reduce the number and the function of immune cells. The intestine is a common site of opportunistic infection and the main symptoms are diarrhoea associated with progressive weight loss. Diarrhoea in immunocompromised patients can be caused by common pathogens, including viruses, fungi, bacteria and protozoa, in particular Criptosporidium parvum and Giardia species (139). Current treatments include antibiotics, blood transfusions, corticosteroids, dietary supplements, immunomodulatory and antiviral drugs which may only help to alleviate symptoms and may cause strong side effects (140). In this regard, alternative and/or adjuvant strategies should be evaluated. Several studies have suggested that BC might improve the clinical conditions of HIV-associated diarrhoea, probably thanks to the synergic action of several biologically active molecules contained in BC $(93,141,142)$. Good results have been obtained by administering colostrum to human patients which has improved clinical conditions by reducing abdominal pain, diarrhoea score and fatigue $(91,143)$. In another study BC reduced daily stool frequency and increased the body weight and body mass index and CD4+ count respect to the control (144). Furthermore, a lipid defined as sporozoites inhibiting the adhesion of lipid (SIL) has been identified in colostrum and the intestinal mucosa of calves fed with colostrum, which also acts against Giardia (145). Colostrum has been used effectively for reducing the clinical signs and elimination of oocysts in various animal species (146). This suggests that $\mathrm{BC}$ can ameliorate HIV-associated diarrhoea, probably through direct antimicrobial and endotoxin-neutralizing effects, thus suppressing bacterial translocation and gut inflammation as well as favouring mucosal integrity and tissue repair $(6,12,51,138)$. Further research must be carried out to confirm these findings.

\subsection{Inflammatory bowel disease (IBD)}

Are a heterogeneous group of chronic, multifactorial, relapsing inflammatory diseases of the gastro-intestinal tract (147). Common clinical signs observed in IBD patients are chronic diarrhoea, vomiting and weight loss associated to histopathological evidence of inflammation in various portions of GI tract. In humans, Crohn's disease (CD) and ulcerative colitis (UC) are the principal types of IBD. In pets, especially in dogs, several kinds of chronic diseases have been reported which present both differences and similarities with human IBD (148). While the exact aetiology of IBD remains unknown, several clinical studies suggest that interplay between genetic, environmental, immune factors and enteric bacteria play a critical role in the development of the disease (149). It has been suggested that atypical intestinal microbiota induces an incorrect activation of the gut immune system resulting in loss of tolerance and consequently a chronic inflammation of the digestive tract in genetically predisposed subjects (150). Intestinal microbiota confer important functions to the host including mucosal barrier, metabolic and immune regulatory functions (151). Evidence from recent molecular studies revealed differences in the intestinal microbiome between healthy individuals and IBD patients with a reduction of beneficial and an increase of potentially dangerous bacteria (152). Current therapy for treating IBD includes the administration of aminosalicylate, steroids, immunosuppressive agents and antibiotics; although it is not curative and has several side effects (153). New approaches are required for the prevention and/or treatment of IBD, and BC can represent a safe, low cost option (154). Prophylactic administration of $\mathrm{BC}$ reduced weight loss, decreased colon shortening and improved the histologic severity of colon inflammation in dextran sulfate sodium-induced colitis in mice. Furthermore, these beneficial effects were accompanied by the reorganisation of immunoregulatory cells (155). In the same animal model of colitis, BC therapy improved occult blood, stool consistency, and clinical recovery from colon inflammation but did not reduce body weight loss (156). BC enema resulted in the improvement of clinical signs and histological scores in human patients affected by active colitis compared to control (157). It is possible that BC components can balance intestinal microbiota thus favouring the growth of beneficial bacteria that in turn reinforce the mucosal barrier function, neutralize pathogen agents and reduce the risk of bacterial translocation $(18,100,132,158)$. Other substances included in BC can help to modulate immune system cells and consequently the severity of inflammatory response while colostrum can induce epithelial regeneration $(2,51,70,94,99,100,124)$.

\subsection{Necrotizing enterocolitis (NEC)}

Is a serious disease characterized by severe ulceration of the small and large intestine that affects infants and mainly pre-term neonates. The precise aetiology of NEC remains unknown, although several structural and functional deficiencies related to epithelial barrier integrity, digestive and absorptive capacity, intestinal mobility, gut microbiota and immunological dysfunctions are definitely involved in the development and progression of the disease $(159,160)$. Maldigestion and intestinal stasis commonly observed in preterm infants can lead to abnormal gut microflora, bacterial translocation and sepsis, which contribute to an aberrant activation of the immune system and finally to uncontrolled inflammation (161). A feasible strategy for reducing the incidence of NEC could be to control the type of diet and feeding mode since the maturation of the gastrointestinal tract, bacterial colonization and the modulation of the immune system depend on these factors $(123,162-164)$. 
The synergic action of biologically active components of $\mathrm{BC}$ may contribute to the maturation of the digestive tract, in balancing gut microbiota, modulation of the intestinal immune system and mucosal repair $(2,10,12,57,124)$. Colostrum has proved to have beneficial effects and therefore may represent an adjuvant therapy (165-167). It was suggested that $B C$ is effective in stimulating gut structure, function, and NEC resistance in preterm piglets (168). Animals fed with $B C$ had a longer intestinal transit time, higher weight gain, absorptive capacity and enzyme activities compared to piglets fed with infant formula. At the same time, BC reduced NEC incidence, pro-inflammatory cytokines concentration such as IL-8 and reduced histological lesions (169). BC proved to have beneficial effects on NEC development and intestinal function in a piglet model and these data were confirmed by an in vitro study in which a modulatory action of colostrum proteins in cytokines secretion from bacteria-stimulated murine bone marrowderived dendritic cells was observed (170). An in vitro study suggested that pretreatment with $\mathrm{BC}$ significantly reduced several bacteria specie (Enterobacter cloacae, Klebsiella oxytoca, Escherichia coli, Serratia marcescens and Klebsiella pneumonia) in attachment to HT-29 cells, although the treatment increased the levels of some proinflammatory cytokines (171). Intestinal function was restored by $\mathrm{BC}$ administration after initial formula-induced inflammation in a pig model of NEC. NEC severity and pro-inflammatory cytokine (IL-1 $\beta$ and IL-8) concentrations were lower, while villus height, galactose absorption, and brush-border enzyme activities increased in the intestines of the piglets fed with colostrum compared to the control $(172,173)$. In clinical studies, the piglets fed with infant formula showed higher percentages of NEC development, structural damage, reduced functional activity and antioxidant levels and bacterial overgrowth compared to animals fed with BC $(167,174)$. Colostrum administration may decrease clinical sepsis, inhibit secretion of pro-inflammatory cytokines and increase levels of circulating immune-protective factors in extremely premature infants (175). Nevertheless, further studies are required to confirm these encouraging results and to determine whether BC could be used as an effective substitute of mother's milk for preterm infants.

\subsection{Short bowel syndrome (SBS)}

Is characterized by insufficient length of the intestine due to surgical amputation and it is associated with poor digestion and absorption. The most common therapeutic option is parenteral nutrition but other strategies are required in order to improve the outcome of patients that depend on the functional adaptation of the remaining intestine. Colostrum contains immunoregulatory, antimicrobial and trophic components that can support intestinal development and function in neonates and could also enhance intestinal adaptation and functions $(2,37,94,172)$. A possible strategy for improving conditions of patients is to decrease the intestinal transit of nutrients and allow a longer mucosal contact time for their absorption by increasing muscular adaptation. Colostrum supplement induces muscular hypertrophy increasing the muscle width and the number of cells and these changes may be mediated by the simultaneous increase of the serum concentrations of IGF-1 and IGF binding proteins after small intestinal resection in piglets (176). In a pig model of SBS colostrum induced intestinal adaptation, the piglets that underwent massive intestinal resection showed the same weight gain and greater villus length and crypt depth in the jejunum and ileum compared to the control (177). On the contrary, in a randomized controlled trial Lund et al., observed that in spite of it high content of bioactive factors, colostrum did not significantly increase intestinal functions, absorption and body composition compared with the control (178). Feeding the piglets with colostrum supplement increased intestinal proliferation significantly (179). Furthermore, the high levels of specific growth factors contained in colostrum may prove to be beneficial. Systemic administration of EGF stimulates intestinal growth in rats receiving parenteral nutrition $(57,68)$. In rabbits that underwent intestinal resection, the oral administration of EGF proved to restore glucose transport (180). Therapeutic use of colostrum in SBS may be especially useful for treating children given that gut adaptation is better during the development of the gastro-intestinal tract rather than in adults. Additional research is required in order to determine whether this practice can improve the outcome of patients with SBS.

\subsection{Surgery}

Nosocomial infections present serious clinical issues in surgery despite the progress made in hygiene, surgical techniques and intensive care medicine. Under conditions of shock caused by injury or surgery, bacteria and endotoxins in the intestines can cross the mucosal barrier by translocation and enter the blood and lymphatic system sometimes causing a dangerous systemic inflammatory response syndrome (SIRS) and a multiple organ dysfunction syndrome (MODS) (181). In humans, bacterial translocation has a prevalence of approximately $15 \%$ in elective surgical patients and occurs more frequently in patients undergoing abdominal surgery, organ donors and intestinal obstruction, but is also evident in patients with chronic inflammatory bowel diseases, ischaemia-reperfusion injury shock, pancreatitis and immunocompromised subjects $(132,182)$. In general, current therapeutic options include coadministration of fluids and vasopressors to preserve blood pressure, blood in the event of bleeding, antibiotics to counteract infections and bacterial translocation, corticosteroids or NSAIDs to control inflammation, painkillers or other analgesic drugs and diet control. In this context, colostrum administered before or after surgery could play a complementary role to conventional therapy with the aim of reducing the risk of complications. Colostrum has been identified as being a preventive treatment in pre-operatory abdominal and 
coronary arteries surgery. In abdominal surgery it reduced endotoxemia while in coronary bypass surgery it reduced IL-6 and C-reactive protein levels although it did not have any effect on endotoxemia $(183,184)$. Several in vitro and in vivo studies have been carried out to evaluate the effectiveness of colostrum in preventing bacterial translocation, endotoxaemia and increasing morphophysiological adaptation after small bowel surgery in rats and rabbits $(132,138,185,186)$. It is believed that preoperative treatment with colostrum, associated with conventional therapy, may reduce bacterial translocation and endotoxemia thus favouring the recovery of both human and animal surgical patients $(99,132,187)$. It contains numerous components that can directly or indirectly affect the various pathogenetic steps of the complications linked to surgery $(20,97)$. Furthermore, the synergic activities of components present in colostrum can be useful in the postoperative period to ensure wound healing and the recovery of absorptive functions $(129,162,176,188)$.

\subsection{Side effects and contraindications}

According to the current state of knowledge, colostrum appears to be safe and no contraindications are observed even when administered at high concentrations both in humans and animals $(189,190)$. Some authors have reported lactose intolerance, nausea, flatulence, transient diarrhoea and unspecified abdominal discomfort as possible side effects while other studies specifically reported the absence of side effects $(83,128,129,165,137,143,189,190)$. However, further research is required in order to confirm these data, and, more importantly, to evaluate the effects of colostrum when used for a prolonged periods of time and during pregnancy. Milk allergy is the most frequent food allergy in infancy and childhood. Like milk colostrum contains caseins, a-lactalbumin and $\beta$-lactoglobulin, and other minor proteins (immunoglobulins, bovine serum albumin) that are deemed to be the main allergens (191). For this reason, colostrum is not recommended for treating individuals who are sensitive to milk proteins.

\section{CONCLUSION}

Colostrum is a rich source of nutrients and biologically active molecules that are essential for several specific functions including defensive action, the modulation of immune response, the balancing of intestinal microbiota and the growth and repair of several tissues. The components of colostrum, acting synergistically, can intervene in various pathogenetic phases of several diseases, thus contributing to an improvement of clinical symptoms. Colostrum may also have a preventive action or reduce the side effects of several drugs that are currently used for treating various diseases of humans and animals. It may also play an important role in accelerating the recovery of health and body weight during convalescence. More generally, colostrum may be administered with the aim of maintaining a good health status, strengthening the immune system and preventing disease. Current farming methods foresee the production of large quantities of raw colostrum for continuous availability. Colostrum used as supplement must be of high quality and a standardization of the product is required. Pharmaceutical companies aim to produce commercial products containing bovine colostrum while biotechnology companies attempting to clone and produce large quantities of its main components. The growing interest in this natural biological fluid is supported by the encouraging results obtained in scientific studies and clinical trials carried out both in vitro and in vivo in humans and animals, although further research is required to confirm its potential and long-term effects. Colostrum is safe and does not have contraindications even at high dose levels and there are few reported side effects of clinical relevance. Therefore in the near future, this "first milk" may play a complementary role to synthetic pharmaceutical drugs, in the prevention and treatment of several diseases of humans and animals and it may improve the daily health of populations in developing countries.

\section{ACKNOWLEDGEMENTS}

This study is part of the PhD program in "Animal health, livestock production and food safety" XXVIII cycle carried out by Dr L. Menchetti and supported by Operational Programme of the Umbria Region (POR Umbria FSE 2007/2013 Asse Capitale Umano - Obiettivo specifico "l" Progetto "Promozione della ricerca e dell'Innovazione") and by the University of Perugia. The authors gratefully acknowledge the revision of the English text by Eleanor Fabri.

\section{REFERENCES}

1. P Langer: Differences in the Composition of Colostrum and Milk in Eutherians Reflect Differences in Immunoglobulin Transfer. J Mammal 90 (2), 332-9 (2009) DOI: 10.1644/08-MAMM-A-071.1

2. RL Shen, $T$ Thymann, MV Østergaard, AC Støy, $Ł$ Krych, DS Nielsen, C Lauridsen, B Hartmann, JJ Holst, DG Burrin, PT Sangild: Early gradual feeding with bovine colostrum improves gut function and NEC resistance relative to infant formula in preterm pigs. Am J Physiol Gastrointest Liver Physiol 309 (5), 310-23 (2015)

DOI: 10.1152/ajpgi.00163.2015

3. B Lonnerdal: Bioactive proteins in breast milk. J Paediatr Child Health 49 (Suppl1), 1-7 (2013) 
DOI: 10.1111/jpc.12104

4. SI Kehoe, BM Jayarao, AJ Heinrichs: A survey of bovine colostrum composition and colostrum management pratictices on Pennsylvania diry farms. J Dairy Sci 90 (9), 4108-16 (2007) DOI: $10.3168 / j d s .2007-0040$

5. K Stelwagen, E Carpenter, B Haigh, A Hodgkinson, TT Wheeler: Immune components of bovine colostrum and milk. J Anim Sci 87 (Suppl13), 3-9 (2009)

DOI: 10.2527/jas.2008-1377

6. KF Benson, SG Carter, KM Patterson, D Patel, GS Jensen: A novel extract from bovine colostrum whey supports anti-bacterial and anti-viral innate immune functions in vitro and in vivo I. Enhanced immune activity in vitro translates to improved microbial clearance in animal infection models. Prev Med 54, 116-23 (2011)

DOI: 10.1016/j.ypmed.2011.12.023

7. RM Lawrence, CA Pane: Human breast milk: current concepts of immunology and infectious diseases. Curr Probl Pediatr Adolesc Health Care 37 (1), 7-37 (2007)

DOI: 10.1016/j.cppeds.2006.10.002

8. TT Wheeler, AJ Hodgkinson, CG Prosser, SR Davis: Immune components of colostrums and milk: a historical perspective. J Mammary Gland Biol Neoplasia 12 (4), 237-47 (2007)

DOI: 10.1007/s10911-007-9051-7

9. M Janusz, A Zabłocka: Colostrinin: a proline-rich polypeptide complex of potential therapeutic interest. Cell Mol Biol 59 (1), 4-11 (2013)

doi not found

10. RJ Playford: Peptide therapy and the gastroenterologist: colostrum and milkderived growth factors. Clin Nutr 20 (Suppl1), 101-6 (2001)

DOI: $10.1054 / \mathrm{clnu} .2001 .0434$

11. KS Kelly: Bovine colostrums: A review of clinical uses. Altern Med Rev 8 (4), 378-94 (2004)

doi not found

12. $\mathrm{H}$ Li, RE Aluko: Bovine colostrum as a bioactive product against human microbial infections and gastrointestinal disorders. Curr Top Nutraceutical Res 4 (3-4), 227-37 (2006) doi not found
13. L Elfstrand, $\mathrm{H}$ Lindmark-Månsson, $\mathrm{M}$ Paulssona, L Nybergc, B Akesson: Immunoglobulins, growth factors and growth hormone in bovine colostrum and the effects of processing. Int Dairy J 12 (11), 879-87 (2002) DOI: 10.1016/S0958-6946(02)00089-4

14. M Moore, WJ Tyler, M Chigerwe, ME Dawes, JR Middleton: Effect of delayed colostrum collection on colostral lgG concentration in dairy cows. J Am Vet Med Assoc 226 (8), 1375-7 (2005)

DOI: 10.2460/javma.2005.226.1375

15. AK Dang, S Kapila, MPC Singh: Changes in colostrum of Murrah buffaloes after calving. Trop Anim Health Prod 41 (7), 1213-7 (2009) DOI: $10.1007 / \mathrm{s} 11250-008-9302-7$

16. H Korhonen, A Pihlanto: Technological options for the production of health-promoting proteins and peptides derived from milk and colostrums. Curr Pharm Des 13 (8), 829-43 (2007)

DOI: $10.2174 / 138161207780363112$

17. BL Larson, HL Jr Heary, JE Devery: Immunoglobulin production and transport by the mammary gland. J Dairy Sci 63 (4), 665-71 (1980)

DOI: 10.3168/jds.S0022-0302(80)82988-2

18. EM Lilius, P. Marnila: The role of colostral antibodies in prevention of microbial infections. Curr Opin Infect Dis 14 (3), 295-300 (2001) DOI: 10.1097/00001432-200106000-00008

19. R Mehra, P Marnila, H Korhonen: Milk immunoglobulins for health promotion. Int Dairy J 16 (11), 1262-71 (2006)

DOI: 10.1016/j.idairyj.2006.06.003

20. JK Sponseller, JA Steele, DJ Schmidt, HB Kim, G Beamer, X Sun, S Tzipori: Hyperimmune Bovine Colostrum as a Novel Therapy to Combat Clostridium difficile Infection. J Infect Dis 211 (8), 1334-41 (2015)

DOI: $10.1093 /$ infdis/jiu605

21. S Hiss, $T$ Meyer, $H$ Sauerwein: Lactoferrin concentrations in goat milk throughout lactation. Small Rumin Res 80 (1-3), 87-90 (2008)

DOI: 10.1016/j.smallrumres.2008.07.027

22. D Legrand, E Elass, M Carpentier, J Mazurier: Lactoferrin: a modulator of immune and inflammatory responses. Cell Nol Life Sci 62 (22), 2549-59 (2005) 
DOI: 10.1007/s00018-005-5370-2

23. N Anand, RK Kanwar, ML Dubey, RK Vahishta, R Sehgal, AK Verma, JR Kanwar: Effect of lactoferrin protein on red blood cells and macrophages: mechanism of parasitehost interaction. Drug Des Devel Ther 9, 821-35 (2015)

doi not found

24. MM Rahman, WS Kim, T Ito, H Kumura, K Shimazaki: Growth promotion and cell binding ability of bovine lactoferrin to Bifidobacterium longum. Anaerobe 15 (4), 133-7 (2009)

DOI: 10.1016/j.anaerobe.2009.01.003

25. V Buccigrossi, G de Marco, E Bruzzese, Ombrato L, I Bracale, G Polito, Guarino A: Lactoferrin induces concentration-dependent functional modulation of intestinal proliferation and differentiation. Pediatr Res 61 (4), 410-4 (2007)

DOI: 10.1203/pdr.0b013e3180332c8d

26. J Artym, M Zimecki: Milk-derived proteins and peptides in clinical trials. Postepy Hig Med Dosw (Online) 67, 800-16 (2013)

DOI: $10.5604 / 17322693.1061635$

27. J Przybylska, E Albera, M Kankofer: Antioxidants in bovine colostrum. Reprod Domest Anim 42 (4), 402-9 (2007)

DOI: 10.1111/j.1439-0531.2006.00799.x

28. L Ahmed, SK Nazul Islam, MNI Khan, S Huque, M Ashan: Antioxidant micronutrient profile (vitamin E, C, A, Cooper, Zinc, Iron) of colostrums: association with maternal characteristics. J Trop Pediatr 50 (6), 357-8 (2004)

DOI: 10.1093/tropej/50.6.357

29. A Belo, T Marchbank, A Fitzgerald, S Ghosh, RJ Playford: Gastroprotective effects of oral nucleotide administration. Gut 55 (2), 165-71 (2006)

DOI: 10.1136/gut.2005.076752

30. WH Yu: Scientific rationale and benefits of nucleotide supplementation of infant formula. J Paediatr Child Health 38 (6), 543-9 (2002) DOI: 10.1046/j.1440-1754.2002.00056.x

31. XL Pan, T Izumi: Variation of the ganglioside compositions of human milk, cow's milk and infant formulas. Early Hum Dev 57 (1), 25-31 (2000)

DOI: 10.1016/S0378-3782(99)00051-1

32. R Rueda: The role of dietary gangliosides on immunity and the prevention of infection. $\mathrm{Br} \mathrm{J}$ Nutr 98 (Suppl1), 68-73 (2007)

DOI: $10.1017 / S 0007114507832946$

33. T Idot, H Kawakami: Inhibitory effects of milk gangliosides on the adhesion of escherichia coli to human intestinal carcinoma cells. Biosci Biotech Biochem 59 (1), 69-72 (1995) DOI: 10.1271/bbb.59.69

34. T Nakano, M Sugawara, H Kawakami: Sialic acid in human milk: composition and functions. Acta Paediatr Taiwan 42 (1), 11-7 (2001) doi not found

35. T Urashima, E Taufik, K Fukuda, S Asakuma: Recent advances in studies on milk oligosaccharides of cows and other domestic farm animals. Biosci Biotechnol Biochem 77 (3), 455-66 (2013)

DOI: $10.1271 / \mathrm{bbb} .120810$

36. T Urashima, K Fukuda, M Messer: Evolution of milk oligosaccharides and lactose: a hypothesis. Animal 6 (3), 369-74 (2012)

DOI: $10.1017 / S 1751731111001248$

37. DS Newburg: Neonatal protection by an innate immune system of human milk consisting of oligosaccharides and glycans. J Anim Sci 87 (Suppl13), 26-34 (2009)

DOI: 10.2527/jas.2008-1347

38. H Tlaskalová-Hogenová, R Štepánková, T Hudcovic, L Tucková, B Cukrowska, R Lodinová-Žádnıková: Commensal bacteria (normal microflora), mucosal immunity and chronic inflammatory and autoimmune diseases. Immunol Lett 93, (2-3), 97-108 (2004)

DOI: 10.1016/j.imlet.2004.02.005

39. S Jara, M Sánchez, R Vera, J Cofré, E Castro: The inhibitory activity of Lactobacillus spp. isolated from breast milk on gastrointestinal pathogenic bacteria of nosocomial origin. Anaerobe 17 (6), 474-7 (2011)

DOI: 10.1016/j.anaerobe.2011.07.008

40. A Sokolowska, R Bednarz, M Pacewicz, JA Georgiades, T Wilusz, A Polanowski: Colostrum from different mammalian species-A rich source of colostrinin. Int Dairy J 18 (2), 204-9 (2008)

DOI: 10.1016/j.idairyj.2007.08.004

41. M Janusz, J Lisowski: Proline-rich polypeptide (PRP)—an immunomodulatory peptide from bovine colostrums. Arch Immun Et Ther Exper 
41 (5-6), 275-9 (1993)

doi not found

42. I Boldogh, L Aguilera-Aguirre, A Bacsi, BK Choudhury, A Saavedra-Molina, M Kruzel: Colostrin decreases hypersensitivity and allergic responses to common allergens. Int Arch Allergy Immunol 146 (4), 298-306 (2008) DOI: 10.1159/000121464

43. MG Stewart: New insight into mode of action of Colostrinin. J Nutr Health Aging 14 (4), 336 (2010)

DOI: 10.1007/s12603-010-0076-z

44. AZabłocka, A Ogorzałek, J Macała, M Janusz: A proline-rich polypeptide complex (PRP) influences inducible nitric oxide synthase in mice at the protein level. Nitric Oxide 23 (1), 20-5 (2010)

DOI: 10.1016/j.niox.2010.03.003

45. M Janusz, A Zabłocka: Colostral prolinerich polypeptides--immunoregulatory properties and prospects of therapeutic use in Alzheimer's disease. Curr Alzheimer Res 7 (4), 323-33 (2010)

DOI: $10.2174 / 156720510791162377$

46. A Bacsi, GJ Stanton, TK Hughes, M Kruzel, I Boldogh: Colostrinin-driven neurite outgrowth requires p53 activation in $\mathrm{PC} 12$ cells. Cell Mol Neurobiol 25 (7), 1123-39 (2005)

DOI: 10.1007/s10571-005-8222-6

47. DA Camfield, L Owen, AB Scholey, A Pipingas, C Stough: Dairy constituents and neurocognitive health in ageing. $\mathrm{Br} J$ Nutr 106 (2), 159-74 (2011)

DOI: $10.1017 / S 0007114511000158$

48. R Garofalo: Cytokines in human milk. J Pediatr 156 (Suppl2), 36-40 (2010)

DOI: 10.1016/j.jpeds.2009.11.019

49. K Hagiwara, S Kataoka, H Yamanaka, R Kirisawa, H Iwai: Detection of cytokines in bovine colostrums. Vet Immunol Immunopathol 76 (3-4), 183-90 (2000)

DOI: 10.1016/S0165-2427(00)00213-0

50. MM Sira, T Yoshida, M Takeuchi, Y Kashiwayama, T Futatani, H Kanegane, A Sasahara, Y Ito, M Mizuguchi, T Imanaka, T Miyawaki: A novel immunoregulatory protein in human colostrum, syntenin-1, for promoting the development of IgA-producing cells from cord blood B cells. Int Immunol 21 (9), 1013-23 (2009)
DOI: 10.1093/intimm/dxp067

51. CM Shing, JM Peake, K Suzuki, DG Jenkins, JS Coombes: Bovine colostrum modulates cytokine production in human peripheral blood mononuclear cells stimulated with lipopolysaccharide and phytohemagglutinin. J Interferon Cytokine Res 29 (1), 37-44 (2009) DOI: 10.1089/jir.2008.0015

52. DC Donovan, AJ Reber, J Gabbard, M Aceves-Avila, KL Galland, K Holbert, LO Ely, DJ Hurley: Effect of maternal cells transferred with colostrum on cellular responses to pathogen antigens in neonatal calves. $A m \mathrm{~J}$ Vet Res 68 (7), 778-82 (2007)

DOI: 10.2460/ajvr.68.7.778

53. AJ Reber, DC Donovan, J Gabbard, K Galland, M Aceves-Avila, KA Holbert, L Marshall, DJ Hurley: Transfer of maternal colostral leukocytes promotes development of the neonatal immune system I. Effects on monocyte lineage cells. Vet Immunol Immunopathol 123 (3-4), 186-96 (2008)

DOI: 10.1016/j.vetimm.2008.01.034

54. JF Kuemmerle: Insulin-like growth factors in the gastrointestinal tract and liver. Endocrinol Metab Clin North Am 41 (2), 409-23 (2012) DOI: 10.1016/j.ecl.2012.04.018

55. JW Blum, CR Baumrucker: Colostral insulinlike growth factors and related substances: mammary gland, and neonatal (intestinal and systemic) targets. Domest Anim Endocrinol 23 (1-2), 101-10 (2002)

DOI: 10.1016/S0739-7240(02)00149-2

56. PM Jehle, RD Fussgaenger, WF Blum, NK Angelus, A Hoeflich, E Wolf, RJ Jungwirth: Differential autocrine regulation of intestinal epithelial cell proliferation and differentiation by insulin-like growth factor (IGF) system component. Horm Metab Res 31 (2-3), 97-102 (1999)

DOI: $10.1055 / \mathrm{s}-2007-978705$

57. M Good, CP Sodhi, CE Egan, A Afrazi, H Jia, Y Yamaguchi, P Lu, MF Branca, C Ma, T Jr Prindle, S Mielo, APompa, ZHodzic, JAOzolek, DJ Hackam: Breast milk protects against the development of necrotizing enterocolitis through inhibition of Toll-like receptor 4 in the intestinal epithelium via activation of the epidermal growth factor receptor. Mucosal Immunol 8 (5), 1166-79 (2015)

DOI: $10.1038 / \mathrm{mi} .2015 .30$ 
58. JF Thompson, M Van Den Berg, PCF Stokkers: Developmental regulation of epidermal growth factor receptor kinase in rat intestine. Gastroenterology 107 (5), 1278-87 (1994)

DOI: 10.1016/0016-5085(94)90528-2

59. H Okuyama, M Urao, D Lee, RA Drongowski, AG Coran: The effect of epidermal growth factor on bacterial translocation in newborn rabbits. J Pediatr Surg 33 (2), 225-8 (1998) DOI: 10.1016/S0022-3468(98)90436-5

60. SA Cartlidge, JB Elder: Transforming growth factor $\alpha$ and EGF levels in normal human gastrointestinal mucosa. Br J Cancer 60 (5), 657-60 (1989)

DOI: 10.1038/bjc.1989.334

61. S Koyama, DK Podolsky: Differential expression of transforming growth factors $\alpha$ and $\beta$ in rat intestinal epithelial cells. $J$ Clin Invest 83 (5), 1768-73 (1989)

DOI: $10.1172 / \mathrm{JCl} 114080$

62. DN Nguyen, PT Sangild, MV Ostergaard, SB Bering, DE Chatterton: Transforming growth factor- $\beta 2$ and endotoxin interact to regulate homeostasis via interleukin-8 levels in the immature intestine. Am J Physiol Gastrointest Liver Physiol 307 (7), 689-99 (2014)

DOI: 10.1152/ajpgi.00193.2014

63. J Ogawa, A Sasahara, T Yoshida, MM Sira, T Futatani, H Kanegane, T Miyawaki: Role of transforming growth factor-beta in breast milk for initiation of IgA production in newborn infants. Early Hum Dev 77 (1-2), 67-75 (2004) DOI: 10.1016/j.earlhumdev.2004.01.005

64. YW Shing, M Klagsbrun: Human and bovine milk contain different sets of growth factors. Endocrinology 115 (1), 273-82 (1984)

DOI: 10.1210/endo-115-1-273

65. PJ Keck, SD Hauser, G Krivi, K Sanzo, T Warren, J Feder, DT Connolly: Vascular permeability factor, an endothelial cell mitogen related to PDGF. Science 246 (4935), 1309-12 (1989)

DOI: $10.1126 /$ science. 2479987

66. CG Siafakas, F Anatolitou, RD Fusunyan, WA Walker, IR Sanderson: Vascular endothelial growth factor (VEGF) is present in human breast milk and its receptor is present on intestinal epithelial cells. Pediatr Res 45 (5Pt1), 652-7 (1999)

DOI: 10.1203/00006450-199905010-00007
67. P Rawal, V Gupta, BR Thapa: Role of colostrum in gastrointestinal infections. Indian J Pediatr 75 (9), 917-21 (2008)

DOI: $10.1007 / \mathrm{s} 12098-008-0192-5$

68. RJ Playford, CE Macdonald, WS Johnson: Colostrum and milk-derived peptide growth factors for the treatment of gastrointestinal disorders. Am J Clin Nutr 72 (1), 5-14 (2000) doi not found

69. BR Thapa: Therapeutic potentials of bovine colostrums. Indian J Pediatr 72 (10), 849-52 (2005)

DOI: 10.1007/BF02731112

70. M Blais, M Fortier, Y Pouliot, SF Gauthier, $Y$ Boutin, C Asselin, M Lessard: Colostrum whey down-regulates the expression of early and late inflammatory response genes induced by Escherichia coli and Salmonella enterica Typhimurium components in intestinal epithelial cells. Br J Nutr 113 (2), 200-11 (2014)

DOI: $10.1017 / S 0007114514003481$

71. I Shibata, M Ono, M Mori: Passive protection against porcine epidemic diarrhea (PED) virus in piglets by colostrum from immunized cows. J Vet Med Sci 63 (6), 655-8 (2001)

DOI: 10.1292/jvms.63.655

72. G Günaydın, R Zhang, L Hammarström, $H$ Marcotte: Engineered Lactobacillus rhamnosus GG expressing IgG-binding domains of protein $\mathrm{G}$ : Capture of hyperimmune bovine colostrum antibodies and protection against diarrhoea in a mouse pup rotavirus infection model. Vaccine 32 (4), 470-7 (2014) DOI: 10.1016/j.vaccine.2013.11.057

73. M Inagaki, H Muranishi, K Yamada, K Kakehi, K Uchida, T Suzuki, T Yabe, T Nakagomi, O Nakagomi, Y Kanamaru: Bovine $\kappa$-casein inhibits human rotavirus (HRV) infection via direct binding of glycans to HRV. J Dairy Sci 97 (5), 2653-61 (2014)

DOI: 10.3168/jds.2013-7792

74. M Inagaki, M Yamamoto, Cairangzhuoma Xijier, T Yabe, K Uchida, M Kawasaki, T Nakagomi, O Nakagomi, N Minamoto, Y Kanamaru: Multiple-dose therapy with bovine colostrum confers significant protection against diarrhea in a mouse model of human rotavirus-induced gastrointestinal disease. J Dairy Sci 96 (2), 806-14 (2013) DOI: 10.3168/jds.2012-5847 
75. AK Mitra, D Mahalanabis, H Ashraf, L Unicomb, R Eeckels, S Tzipori: Hyperimmune cow colostrum reduces diarrhoea due to rotavirus: a double-blind, controlled clinical trial. Acta Paediatr 84 (9), 996-1001 (1995)

DOI: 10.1111/j.1651-2227.1995.tb13814.x

76. GP Davidson, PB Whyte, E Daniels, KFranklin, H Nunan, PI McCloud, AG Moore, DJ Moore: Passive immunization of children with bovine colostrum containing antibodies to human rotavirus. Lancet 2 (8665), 709-12 (1989) DOI: 10.1016/S0140-6736(89)90771-X

77. RB Turner, DK Kelsey: Passive immunization for prevention of rotavirus illness in healthy infants. Pediatr Infect Dis J 12 (9), 718-22 (1993)

DOI: 10.1097/00006454-199309000-00003

78. H Hilpert, H Brüssow, C Mietens, J Sidoti, $L$ Lerner, $H$ Werchau: Use of bovine milk concentrate containing antibody to rotavirus to treat rotavirus gastroenteritis in infants. $J$ Infect Dis 156 (1), 158-66 (1987)

DOI: 10.1093/infdis/156.1.158

79. D Durand, TJ Ochoa, SM Bellomo, CA Contreras, VH Bustamante, J Ruiz, TG Cleary: Detection of secretory immunoglobulin A in human colostrum as mucosal immune response against proteins of the type III secretion system of Salmonella, Shigella and enteropathogenic Escherichia coli. Pediatr Infect Dis J 32 (10), 1122-6 (2013) DOI: 10.1097/INF.0b013e318293306c

80. W Otto, B Najnigier, T Stelmasiak, RM RobinsBrowne: Randomized control trials using a tablet formulation of hyperimmune bovine colostrum to prevent diarrhea caused by enterotoxigenic Escherichia coli in volunteers. Scand J Gastroenterol 46 (7-8), 862-8 (2011) DOI: 10.3109/00365521.2011.574726

81. CP Champagne, Y Raymond, Y Pouliot, SF Gauthier, M Lessard: Effect of bovine colostrum, cheese whey, and spray-dried porcine plasma on the in vitro growth of probiotic bacteria and Escherichia coli. Can J Microbiol 60 (5), 287-95 (2014)

DOI: 10.1139/cjm-2014-0130

82. DA Vilte, M Larzábal, AA Cataldi, EC Mercado: Bovine colostrum contains immunoglobulin $G$ antibodies against intimin, EspA, and EspB and inhibits hemolytic activity mediated by the type three secretion system of attaching and effacing Escherichia coli. Clin Vaccine Immunol 15 (8), 1208-13 (2008)

DOI: $10.1128 / C V I .00027-08$

83. S Sugiharto, AS Poulsen, N Canibe, C Lauridsen: Effect of bovine colostrum feeding in comparison with milk replacer and natural feeding on the immune responses and colonisation of enterotoxigenic Escherichia coli in the intestinal tissue of piglets. Br J Nutr 113 (6), 923-34 (2015)

DOI: $10.1017 / S 0007114514003201$

84. HI Tawfeek, NH Najim, S Al-Mashikhi: Efficacy of an infant formula containing antiEscherichia coli colostral antibodies from hyperimmunized cows in preventing diarrhea in infants and children: a field trial. Int $J$ Infect Dis 7 (2), 120-8 (2003)

DOI: 10.1016/S1201-9712(03)90007-5

85. CO Tacket, G Losonsky, H Link, Y Hoang, P Guesry, H Hilpert, MM Levine: Protection by milk immunoglobulin concentrate against oral challenge with enterotoxigenic Escherichia coli. N Engl J Med 318 (19), 1240-3 (1988)

DOI: 10.1056/NEJM198805123181904

86. DJ Freedman, CO Tacket, A Delehanty, DR Maneval, J Nataro, JH Crabb: Milk immunoglobulin with specific activity against purified colonization factor antigens can protect against oral challenge with enterotoxigenic Escherichia coli. J Infect Dis 177 (3), 662-7 (1998)

DOI: $10.1086 / 514227$

87. DM Lyerly, EF Bostwick, SB Binion, TD Wilkins: Passive immunization of hamsters against disease caused by Clostridium difficile by use of bovine immunoglobulin $\mathrm{G}$ concentrate. Infect Immun 59 (6), 2215-8 (1991)

doi not found

88. E Mattila, VJ Anttila, M Broas, H Marttila, P Poukka, K Kuusisto, L Pusa, K Sammalkorpi, J Dabek, OP Koivurova, M Vähätalo, V Moilanen, $T$ Widenius: A randomized, doubleblind study comparing Clostridium difficile immune whey and metronidazole for recurrent Clostridium difficile-associated diarrhoea: efficacy and safety data of a prematurely interrupted trial. Scand J Infect Dis 40 (9), 702-8 (2008)

DOI: 10.1080/00365540801964960

89. P Naaber, E Lehto, S Salminen, M Mikelsaar: Inhibition of adhesion of Clostridium difficile to 
Caco-2 cells. FEMS Immunol Med Microbiol 14 (4), 205-9 (1996)

DOI: 10.1111/j.1574-695X.1996.tb00288.x

90. C Akisu, U Aksoy, H Cetin, S Ustun, M Akisu: Effect of human milk and colostrum on Entamoeba histolytica. World J Gastroenterol 10 (5), 741-742 (2004)

DOI: $10.3748 /$ wjg.v10.i5.741

91. PC Okhuysen, CL Chappell, J Crabb, LM Valdez, ET Douglass, HL DuPont: Prophylactic effect of bovine anti-Cryptosporidium hyperimmune colostrum immunoglobulin in healthy volunteers challenged with Cryptosporidium parvum. Clin Infect Dis 26 (6), 1324-29 (1998)

DOI: $10.1086 / 516374$

92. S Tzipori, D Roberton, DA Cooper, L White: Chronic cryptosporidial diarrhoea and hyperimmune cow colostrums. Lancet 2 (8554), 344-5 (1987)

DOI: 10.1016/S0140-6736(87)90944-5

93. PD Greenberg, JP Cello: Treatment of severe diarrhea caused by Cryptosporidium parvum with oral bovine immunoglobulin concentrate in patients with AIDS. J Acquir Immune Defic Syndr Hum Retrovirol 13 (4), 348-54 (1996) DOI: 10.1097/00042560-199612010-00008

94. S Purup, MO Vestergaard, L Pedersen, K Sejrsen: Biological activity of bovine milk on proliferation of human intestinal cells. J Dairy Res 74 (1), 58-65 (2007)

DOI: $10.1017 / S 0022029906002093$

95. KS Chattha, AN Vlasova, S Kandasamy, MA Esseili, C Siegismund, G Rajashekara, LJ Saif: Probiotics and colostrum/milk differentially affect neonatal humoral immune responses to oral rotavirus vaccine. Vaccine 31 (15), 1916-23 (2013)

DOI: 10.1016/j.vaccine.2013.02.020

96. XH Huang, L Chen, W Gao, W Zhang, SJ Chen, LB Xu, SQ Zhang: Specific IgG activity of bovine immune milk against diarrhea bacteria and its protective effects on pathogeninfected intestinal damages. Vaccine 26 (47), 5973-5980 (2008)

DOI: 10.1016/j.vaccine.2008.08.040

97. J Seifert, M Molkewehrum, S Oesser, L Nebermann, C Schulze: Endotoxin inactivation by enterally applied colostrum of different composition. Eur Surg Res 34 (1-2),
68-72 (2002)

DOI: $10.1159 / 000048890$

98. EB Wong, JF Mallet, J Duarte, C Matar, BW Ritz: Bovine colostrum enhances natural killer cell activity and immune response in a mouse model of influenza infection and mediates intestinal immunity through toll-like receptors 2 and 4. Nutr Res 34 (4), 318-25 (2014)

DOI: 10.1016/j.nutres.2014.02.007

99. MJ An, JH Cheon, SW Kim, JJ Park, CM Moon, SY Han, ES Kim, TI Kim, WH Kim: Bovine colostrum inhibits nuclear factor kappa B-mediated proinflammatory cytokine expression in intestinal epithelial cells. Nutr Res 29 (4), 275-80 (2009)

DOI: 10.1016/j.nutres.2009.03.011

100. D Cardani: COLOSTRO NONI administration effects on epithelial cells turn-over, inflammatory events and integrity of intestinal mucosa junctional systems. Minerva Gastroenterol Dietol 60 (1), 71-8 (2014) doi not found

101. R Neiger, KW Simpson: Helicobacter infection in dogs and cats: Facts and fiction. J Vet Intern Med 14 (2), 125-133 (2000)

DOI: 10.1892/0891-6640(2000)014<0125:IID ACF>2.3.CO;2

102. AADos Santos, AA Carvalho: Pharmacological therapy used in the elimination of Helicobacter pylori infection: Areview. World J Gastroenterol 21 (1), 139-154 (2015)

DOI: 10.3748/wjg.v21.i1.139

103. P Marnila, S Rokka, L Rehnberg-Laiho, P Kärkkäinen, TU Kosunen, H Rautelin, ML Hänninen, EL Syväoja, H Korhonen: Prevention and suppression of Helicobacter felis infection in mice using colostral preparation with specific antibodies. Helicobacter 8 (3), 192-201 (2003) DOI: 10.1046/j.1523-5378.2003.00144.x

104. CD Tran, S Kritas, MA Campbell, HQ Huynh, SS Lee, RN Butler: Novel combination therapy for the eradication of Helicobacter pylori infection in a mouse model. Scand $J$ Gastroenterol 45 (12), 1424-30 (2010)

DOI: 10.3109/00365521.2010.506245

105. MMBitzan, BD Gold, DJPhilpott, M Huesca, PM Sherman, H Karch, R Lissner, CA Lingwood, MA Karmali: Inhibition of Helicobacter pylori and Helicobacter mustelae binding to lipid 
receptors by bovine colostrums. J Infect Dis 177 (4), 955-61 (1998)

DOI: $10.1086 / 515256$

106. S Rokka, S Myllykangas, V Joutsjoki: Effect of specific colostral antibodies and selected lactobacilli on the adhesion of Helicobacter pylori on AGS cells and the Helicobacterinduced IL-8 production. Scand J Immunol 68 (3), 280-6 (2008)

DOI: 10.1111/j.1365-3083.2008.02138.x

107. TH Casswall, HO Nilsson, L Björck, S Sjöstedt, L Xu, CK Nord, T Borén, T Wadström, L Hammarström: Bovine anti-Helicobacter pylori antibodies for oral immunotherapy. Scand J Gastroenterol 37 (12), 1380-5 (2002) DOI: 10.1080/003655202762671242

108. MLXu, HJ Kim, HJ Kim: Effect of dietary bovine colostrum on the responses of immune cells to stimulation with bacterial lipopolysaccharide. Arch Pharm Res 37 (4), 494-500 (2014) DOI: $10.1007 / \mathrm{s} 12272-013-0255-7$

109. S Tarpila, H Korhonen, S Salminen: Immune Colostrums in the Treatment of Helicobacter Pylori Gastritis. In: Abstract book of $24^{\text {th }}$ International Dairy Congress, Melbourne, Australia, 293 (1995)

110. M Oona, T Rago, HI Maaroos: Helicobacter pylori in children with abdominal complaints: has immune colostrum some influence on gastritis? Alpe Adria Microbiology $J$ 6 , 49-57 (1997)

111. AR Opekun, HM El-Zaimaity, MS Osato, MA Gilger, HM Malaty, M Terry, DR Headon, DY Graham: Novel therapies for Helicobacter pylori infection. Aliment Pharmacol Ther 13 (1), 35-42 (1999)

DOI: 10.1046/j.1365-2036.1999.00435.x

112. TH Casswall, SA Sarker, MJ Albert, GJ Fuchs, M Bergström, L Björck, L Hammarström: Treatment of Helicobacter pylori infection in infants in rural Bangladesh with oral immunoglobulins from hyperimmune bovine colostrum. Aliment Pharmacol Ther 12 (6), 563-8 (1998)

DOI: 10.1046/j.1365-2036.1998.00335.x

113. J Steele, J Sponseller, D Schmidt, O Cohen, S Tzipori: Hyperimmune bovine colostrum for treatment of GI infections: a review and update on Clostridium difficile. Hum Vaccin Immunother 9 (7), 1565-8 (2013)
DOI: 10.4161/hv.24078

114. ST Sonis: The pathobiology of mucositis. Nat Rev Cancer 4 (4), 277-84 (2004)

DOI: $10.1038 / \mathrm{nrc} 1318$

115. MJ van Vliet, WJ Tissing, CA Dun, NE Meessen, WA Kamps, ES de Bont, HJ Harmsen: Chemotherapy treatment in pediatric patients with acute myeloid leukemia receiving antimicrobial prophylaxis leads to a relative increase of colonization with potentially pathogenic bacteria in the gut. Clin Infect Dis 49 (2), 262-70 (2009)

DOI: $10.1086 / 599346$

116. AM Stringer, RJ Gibson, JM Bowen, RM Logan, K Ashton, AS Yeoh, N Al-Dasooqi, DM Keefe: Irinotecan-induced mucositis manifesting as diarrhoea corresponds with an amended intestinal flora and mucin profile. Int J Exp Pathol 90 (5), 489-99 (2009) DOI: 10.1111/j.1365-2613.2009.00671.x

117. GS Howarth, GL Francis, JC Cool, RW Ballard, LC Read: Milk growth factors enriched from cheese whey ameliorate intestinal damage by methotrexate when administered orally to rats. J Nutr 126 (10), 2519-30 (1996) doi not found

118. HY Chen, O Mollstedt, MH Tsai, RB Kreider: Potential clinical applications of multifunctional milk proteins and peptides in cancer management. Curr Med Chem 21 (21), 2424-37 (2014)

DOI: $10.2174 / 0929867321666140205135739$

119. PE Pontoppidan, RL Shen, MS Cilieborg, P Jiang, $\mathrm{H}$ Kissow, BL Petersen, $\mathrm{T}$ Thymann, C Heilmann, K Müller, PT Sangild: Bovine Colostrum Modulates Myeloablative Chemotherapy-Induced Gut Toxicity in Piglets. J Nutr 145 (7), 1472-80 (2015)

DOI: $10.3945 /$ jn. 114.203430

120. ST Sonis, LLindquist, AVan Vugt, AAStewart, $K$ Stam, GY Qu, KK Iwata, JD Haley: Prevention of chemotherapy-induced ulcerative mucositis by transforming growth factor beta 3. Cancer Res 54 (5), 1135-8 (1994)

doi not found

121. GS Howarth, JC Cool, AJ Bourne, FJ Ballard, LC Read: Insulin-like growth factor-I (IGF-I) stimulates regrowth of the damaged intestine in rats, when administered following, but not concurrent with, methotrexate. Growth 
Factors 15 (4), 279-292 (1998)

DOI: 10.3109/08977199809017483

122. NM Gordler, M McGurk, SAqual, M Prince: The effect of epidermal growth factor mouthwash on cytotoxic-induced oral ulceration. $A m \mathrm{~J}$ Clin Oncol 18 (5), 403-6 (1995)

DOI: 10.1097/00000421-199510000-00009

123. DS Newburg, WA Walker: Protection of the neonate by the innate immune system of developing gut and of human milk. Pediatr Res 61 (1), 2-8 (2007)

DOI: 10.1203/01.pdr.0000250274.68571.18

124. M Cairangzhuoma, H Yamamoto, H Muranishi, M Inagaki, K Uchida, K Yamashita, S Saito, T Yabe, Y Kanamaru: Skimmed, sterilized, and concentrated bovine late colostrum promotes both prevention and recovery from intestinal tissue damage in mice. J Dairy Sci 96 (3), 1347-55 (2013)

DOI: $10.3168 /$ jds.2012-5701

125. AB Yaacov, Y Lichtenstein, L Zolotarov, Y Ilan: The gut microbiome as a target for regulatory $\mathrm{T}$ cell-based immunotherapy: induction of regulatory lymphocytes by oral administration of anti-LPS enriched colostrum alleviates immune mediated colitis. BMC Gastroenterol 15 (1), 154-61 (2015)

DOI: 10.1186/s12876-015-0388-x

126. J Martin, SC Howard, A Pillai, P Vogel, AP Naren, S Davis, K Ringwald-Smith, K Buddington, RK Buddington: The weaned pig as a model for Doxorubicin-induced mucositis. Chemotherapy 60 (1), 24-36 (2014)

DOI: $10.1159 / 000365725$

127. L Trepanier: Drug Interactions and Differential Toxicity of NSAIDs. In: ACVIM Proceedings (2002) doi not found

128. UA Boelsterli, MR Redinbo, KS Saitta: Multiple NSAID-induced hits injure the small intestine: underlying mechanisms and novel strategies. Toxicol Sci 131 (2), 654-67 (2013)

DOI: $10.1093 /$ toxsci/kfs310

129. M Hagiwara, K Kataoka, H Arimochi, T Kuwahara, Y Ohnishi: Role of unbalanced growth of gram-negative bacteria in ileal ulcer formation in rats treated with a nonsteroidal anti-inflammatory drug. J Med Invest 51 (1-2), 43-51 (2004)

DOI: 10.2152/jmi.51.43
130. RD Berg: Bacterial translocation from the gastrointestinal tract. Adv Exp Med Biol 473, 11-30 (1999)

DOI: 10.1007/978-1-4615-4143-1_2

131. S Zhang, B Lü, GQ Chao, FM Chen, MY Chen, HQ Chen: The effects of milk and milk products on non-steroidal anti-inflammatory drug induced intestinal damage in rats. Zhonghua Nei Ke Za Zhi 50 (9), 771-5 (2011) doi not found

132. HS Choi, KH Jung, SC Lee, SV Yim, JH Chung, YW Kim, WK Jeon, HP Hong, YG $\mathrm{Ko}, \mathrm{CH} \mathrm{Kim}, \mathrm{KH}$ Jang, SA Kang: Bovine colostrum prevents bacterial translocation in an intestinal ischemia/reperfusion-injured rat model. J Med Food 12 (1), 37-46 (2009) DOI: 10.1089/jmf.2007.0613

133. R Mir, N Singh, G Vikram, RP Kumar, M Sinha, A Bhushan, P Kaur, A Srinivasan, S Sharma, TP Singh: The structural basis for the prevention of nonsteroidal antiinflammatory drug-induced gastrointestinal tract damage by the C-lobe of bovine colostrum lactoferrin. Biophys J 97 (12), 3178-86 (2009)

DOI: 10.1016/j.bpj.2009.09.030

134. JW Kim, WK Jeon, JW Yun, DI Park, YK Cho, IK Sung, CI Sohn, BI Kim, JS Yeom, HS Park, EJ Kim, MS Shin: Protective effects of bovine colostrum on non-steroidal anti-inflammatory drug induced intestinal damage in rats. Asia Pac J Clin Nutr 14 (1), 103-7 (2005) doi not found

135. EAReznikov, SS Comstock, CYi, N Contractor, SM Donovan: Dietary bovine lactoferrin increases intestinal cell proliferation in neonatal piglets. J Nutr 144 (9), 1401-8 (2014) DOI: 10.3945/jn.114.196568

136. RJ Playford, DN Floyd, CE Macdonald, DP Calnan, RO Adenekan, W Johnson, RA Goodlad, T Marchbank: Bovine colostrum is a health food supplement which prevents NSAID induced gut damage. Gut 44 (5), 653-8 (1999)

DOI: $10.1136 /$ gut.44.5.653

137. RJ Playford, CE MacDonald, DP Calnan, DN Floyd, T Podas, W Johnson, AC Wicks, O Bashir, T Marchbank: Co-administration of the health food supplement, bovine colostrum, reduces the acute non-steroidal anti-inflammatory drug-induced increase in intestinal permeability. Clin Sci (Lond) 100 (6), 
627-33 (2001)

DOI: $10.1042 / \operatorname{cs} 1000627$

138. JW Kim, WK Jeon, EJ Kim: Combined effects of bovine colostrum and glutamine in diclofenac-induced bacterial translocation in rat. Clin Nutr 24 (5), 785-93 (2005)

DOI: 10.1016/j.clnu.2005.04.004

139. NA Feasey, P Healey, MA Gordon: Review article: the aetiology, investigation and management of diarrhoea in the HIV-positive patient. Aliment Pharmacol Ther 34 (6), 587-603 (2011)

DOI: 10.1111/j.1365-2036.2011.04781.x

140. L Elfstrand, $\mathrm{CH}$ Flóren: Management of chronic diarrhea in HIV-infected patients: current treatment options, challenges and future directions. HIV AIDS (Auckl) 2, 219-224 (2010)

DOI: 10.2147/hiv.s13191

141. JA Rump, R Arndt, A Arnold, C Bendick, H Dichtelmüller, M Franke, EB Helm, H Jäger, B Kampmann, P Kolb: Treatment of diarrhoea in human immunodeficiency virus-infected patients with immunoglobulins from bovine colostrum. Clin Investig 70 (7), 588-594 (1992) DOI: $10.1007 / B F 00184800$

142. A Plettenberg, A Stoehr, HJ Stellbrink, H Albrecht, W Meigel: A preparation from bovine colostrum in the treatment of HIV-postive patients with chronic diarrhea. Clin Investig 71 (1), 42-5 (1993)

DOI: 10.1007/BF00210962

143. CH Floren, S Chinenye, L Elfstrand, C Hagman, I Ihse: ColoPlus, a new product based on bovine colostrum, alleviates HIVassociated diarrhoea. Scand J Gastroenterol 41 (6), 682-6 (2006)

DOI: $10.1080 / 00365520500380817$

144. FO Kaducu, SA Okia, G Upenytho, L Elfstrand, $\mathrm{CH}$ Florén: Effect of bovine colostrum-based food supplement in the treatment of HIVassociated diarrhea in Northern Uganda: a randomized controlled trial. Indian $J$ Gastroenterol 30 (6), 270-6 (2011)

DOI: $10.1007 / \mathrm{s} 12664-011-0146-0$

145. J Schmidt, MS Kuhlenschmidt: Microbial adhesion of Cryptosporidium parvum: identification of a colostrum-derived inhibitory lipid. Mol Biochem Parasitol 162 (1), 32-9 (2008)
DOI: 10.1016/j.molbiopara.2008.06.016

146. M Naciri, R Mancassola, JM Reperant, O Canivez, B Quinque, P Yvore: Treatment of experimental ovine cryptosporidiosis with ovine or bovine hyperimmune colostrums. Vet Parasitol 53 (3-4), 173-90 (1994)

DOI: 10.1016/0304-4017(94)90181-3

147. BE Sands: From symptom to diagnosis: clinical distinctions among various forms of intestinal inflammation. Gastroenterology 126 (6), 1518-1532 (2004)

DOI: 10.1053/j.gastro.2004.02.072

148. M Cerquetella, A Spaterna, F Laus, B Tesei, G Rossi, E Antonelli, V Villanacci, G Bassotti: Inflammatory bowel disease in the dog: differences and similarities with humans. World J Gastroenterol 16 (9), 1050-6 (2010) DOI: 10.3748/wjg.v16.i9.1050

149. T Hisamatsu, T Kanai, Y Mikami, K Yoneno, $\mathrm{K}$ Matsuoka, T Hibi: Immune aspects of the pathogenesis of inflammatory bowel disease. Pharmacol Ther 137 (3), 283-97 (2013)

DOI: 10.1016/j.pharmthera.2012.10.008

150. G Bouma, W Strober: The immunological and genetic basis of inflammatory bowel disease. Nat Rev Immunol 3 (7), 521-533 (2003)

DOI: 10.1152/physrev.00045.2009

151. I Sekirov, SL Russell, LC Antunes, BB Finlay: Gut microbiota in health and disease. Physiol Rev 90 (3), 859-904 (2010)

DOI: 10.1152/physrev.00045.2009

152. A Andoh, H Imaeda, T Aomatsu, O Inatomi, S Bamba, M Sasaki, Y Saito, T Tsujikawa, Y Fujiyama: Comparison of the fecal microbiota profiles between ulcerative colitis and Crohn's disease using terminal restriction fragment length polymorphism analysis. J Gastroenterol 46 (4), 479-86 (2011)

DOI: 10.1007/s00535-010-0368-4

153. A Dignass, JO Lindsay, A Sturm, A Windsor, JF Colombel, M Allez, G D'Haens, A D'Hoore, G Mantzaris, G Novacek, T Oresland, W Reinisch, M Sans, E Stange, S Vermeire, S Travis, G Van Assche: Second European evidence-based consensus on the diagnosis and management of ulcerative colitis part 2: current management. J Crohns Colitis 6 (10), 991-1030 (2012)

DOI: 10.1016/j.crohns.2012.09.002

154. M Bellavia F Rappa, M Lo Bello, G Brecchia, 
G Tomasello, A Leone, G Spatola, ML Uzzo, G Bonaventura, S David, P Damiani, I Hajj Hussein, MN Zeenny, A Jurjus, P Schembri-Wismayer, M Cocchi, G Zummo, F Farina, A Gerbino, F Cappello, G Traina: Lactobacillus casei and bifidobacterium lactis supplementation reduces tissue damage of intestinal mucosa and liver after 2,4,6-trinitrobenzenesulfonic acid treatment in mice. J Biol Regul Homeost Agents 28 (2), 251-61 (2014)

doi not found

155. P Bodammer, C Maletzki, G Waitz, J Emmrich: Prophylactic application of bovine colostrum ameliorates murine colitis via induction of immunoregulatory cells. J Nutr 141 (6), 1056-61 (2011)

DOI: 10.3945/jn.110.128702

156. P Bodammer, E Zirzow, S Klammt, C Maletzki, C Kerkhoff: Alteration of DSS-mediated immune cell redistribution in murine colitis by oral colostral immunoglobulin. BMC Immunol $14,10-8$ (2013)

DOI: $10.1186 / 1471-2172-14-10$

157. Z Khan, C Macdonald, AC Wicks, MP Holt, D Floyd, S Ghosh, NA Wright, RJ Playford: Use of the 'nutriceutical', bovine colostrum, for the treatment of distal colitis: results from an initial study. Aliment Pharmacol Ther 16 (11), 1917-22 (2002)

DOI: 10.1046/j.1365-2036.2002.01354.x

158. P Bodammer, C Kerkhoff, C Maletzki, G Lamprecht: Bovine colostrum increases poreforming claudin-2 protein expression but paradoxically not ion permeability possibly by a change of the intestinal cytokine milieu. PLoS One 8 (5), 64210 (2013)

DOI: 10.1371/journal.pone.0064210

159. M Petrosyan, YS Guner, M Williams, A Grishin, HR Ford: Current concepts regarding the pathogenesis of necrotizing enterocolitis. Pediatric Surgery International 25 (4), 309-18 (2009)

DOI: 10.1007/s00383-009-2344-8

160. RH Siggers, J Siggers, $T$ Thymann, M Boye, PT Sangild: Nutritional modulation of the gut microbiota and immune system in preterm neonates susceptible to necrotizing enterocolitis. J Nutr Biochem 22 (6), 511-21 (2011)

DOI: 10.1016/j.jnutbio.2010.08.002
161. DA Kelly: Intestinal failure-associated liver disease: what do we know today? Gastroenterology 130 (2 Suppl 1), 70-7 (2006) DOI: 10.1053/j.gastro.2005.10.066

162. RJ Xu, F Wang, SH Zhang: Postnatal adaptation of the gastrointestinal tract in neonatal pigs: a possible role of milk-borne growth factors. Livest Prod Sci 66 (2), 95-107 (2000)

DOI: 10.1016/S0301-6226(00)00217-7

163. ER Van Haver, PT Sangild, M Oste, JL Siggers, AL Weyns, CJ Van Ginneken: Diet dependent mucosal colonization and interleukin-1beta responses in preterm pigs susceptible to necrotizing enterocolitis. $J$ Pediatr Gastroenterol Nutr 49 (1), 90-8 (2009) DOI: 10.1097/MPG.0b013e31818de393

164. MS Cilieborg, M Boye, L Mølbak, T Thymann, PT Sangild: Preterm birth and necrotizing enterocolitis alter gut colonization in pigs. Pediatr Res 69 (1), 10-6 (2011)

DOI: 10.1203/PDR.0b013e3181ff2a89

165. SM Gephart, M Weller: Colostrum as oral immune therapy to promote neonatal health. Adv Neonatal Care 14 (1), 44-51 (2014) DOI: 10.1097/ANC.0000000000000052

166. MP Sherman, MM Miller, J Sherman, V Niklas: Lactoferrin and necrotizing enterocolitis. Curr Opin Pediatr 26 (2), 146-50 (2014) DOI: 10.1097/MOP.0000000000000068

167. $Y \mathrm{Li}, \mathrm{ML}$ Jensen, DE Chatterton, BB Jensen, T Thymann, AS Kvistgaard, PT Sangild: Raw bovine milk improves gut responses to feeding relative to infant formula in preterm piglets. $A m$ J Physiol Gastrointest Liver Physiol 306 (1), 81-90 (2014) DOI: 10.1152/ajpgi.00255.2013

168. ML Jensen, PT Sangild, $M$ Lykke, $M$ Schmidt, M Boye, BB Jensen, T Thymann: Similar efficacy of human banked milk and bovine colostrum to decrease incidence of necrotizing enterocolitis in preterm piglets. Am J Physiol Regul Integr Comp Physiol 305 (1), 4-12 (2013)

DOI: 10.1152/ajpregu.00094.2013

169. NA Rodriguez, M Vento, EC Claud, CE Wang, MS Caplan: Oropharyngeal administration of mother's colostrum, health outcomes of premature infants: study protocol for a randomized controlled trial. Trials 16 (1), 
453-66 (2015)

DOI: 10.1186/s13063-015-0969-6

170. HK Moller, T Thymann, LN Fink, H Frokiaer, AS Kvistgaard, PT Sangild: Bovine colostrum is superior to enriched formulas in stimulating intestinal function and necrotising enterocolitis resistance in preterm pigs. Br J Nutr 105 (1), 44-53 (2011)

DOI: $10.1017 / S 0007114510003168$

171. HJ Brooks, MA McConnell, J Corbett, GS Buchan, CE Fitzpatrick, RS Broadbent: Potential prophylactic value of bovine colostrum in necrotizing enterocolitis in neonates: an in vitro study on bacterial attachment, antibody levels and cytokine production. FEMS Immunol Med Microbiol 48 (3), 347-54 (2006)

DOI: 10.1111/j.1574-695X.2006.00151.x

172. AC Støy, PM Heegaard, T Thymann, M Bjerre, K Skovgaard, M Boye, B Stoll, M Schmidt, BB Jensen, PT Sangild: Bovine colostrum improves intestinal function following formulainduced gut inflammation in preterm pigs. Clin Nutr 33 (2), 322-9 (2014)

DOI: 10.1016/j.clnu.2013.05.013

173. M Pammi, SA Abrams: Oral lactoferrin for the prevention of sepsis and necrotizing enterocolitis in preterm infants. Cochrane Database Syst Rev 2, CD007137 (2015)

DOI: 10.1002/14651858.cd007137.pub4

174. PT Sangild, RH Siggers, M Schmidt, J Elnif, CR Bjornvad, T Thymann, ML Grondahl, AK Hansen, SK Jensen, M Boye, L Moelbak, RK Buddington, BR Weström, JJ Holst, DG Burrin: Diet- and colonization-dependent intestinal dysfunction predisposes to necrotizing enterocolitis in preterm pigs. Gastroenterology 130 (6), 1776-92 (2006)

DOI: 10.1053/j.gastro.2006.02.026

175. J Lee, HS Kim, YH Jung, KY Choi, SH Shin, EK Kim, JH Choi: Oropharyngeal colostrum administration in extremely premature infants: an RCT. Pediatrics 135 (2), 357-66 (2015) DOI: 10.1542/peds.2014-2004

176. PM Pereira-Fantini, SL Thomas, RG Taylor, E Nagy, M Sourial, PJ Fuller, JE Bines: Colostrum supplementation restores insulinlike growth factor -1 levels and alters muscle morphology following massive small bowel resection. J Parenter Enteral Nutr 32 (3), 266-75 (2008)
DOI: 10.1177/0148607108316197

177. ES Nagy, MC Paris, RG Taylor, PJ Fuller, M Sourial, F Justice, JE Bines: Colostrum protein concentrate enhances intestinal adaptation after massive small bowel resection in juvenile pigs. J Pediatr Gastroenterol Nutr 39 (5), 487-92 (2004)

DOI: 10.1097/00005176-200411000-00008

178. P Lund, PT Sangild, L Aunsholt, B Hartmann, JJ Holst, J Mortensen, PB Mortensen, PB Jeppesen: Randomised controlled trial of colostrum to improve intestinal function in patients with short bowel syndrome. Eur $J$ Clin Nutr 66 (9), 1059-654 (2012)

DOI: 10.1038/ejcn.2012.93

179. D Kelly, TP King, M McFadyen, AGP Coutts: Effect of preclosure colostrum intake on the development of the intestinal epithelium of artificially reared piglets. Biol Neonate 64 (4), 235-44 (1993)

DOI: $10.1159 / 000243995$

180. W O'Loughlin, M Winter, A Shun, JA Hardin, DG Gall: Structural and functional adaptation following jejunal resection in rabbits: effect of epidermal growth factor. Gastroenterology 107 (1), 87-93 (1994)

doi not found

181. JW Alexander, ST Boyce, GF Babcock, L Gianotti, MD Peck, DL Dunn, T Pyles, CP Childress, SK Ash: The process of microbial translocation. Ann Surg 212 (4), 496-510 (1990)

DOI: 10.1097/00000658-199010000-00012

182. H Tsujimoto, S Ono, H Mochizuki: Role of translocation of pathogen-associated molecular patterns in sepsis. Dig Surg 26 (2), 100-9 (2009)

DOI: $10.1159 / 000206143$

183. E Bolke, PM Jehle, F Hausmann, A Däubler, $\mathrm{H}$ Wiedeck, G Steinbach, M Storck, K Orth: Preoperative oral application of immunoglobulin- enriched colostrum milk and mediator response during abdominal surgery. Shock 17 (1), 9-12 (2002)

DOI: $10.1097 / 00024382-200201000-00002$

184. E Bolke, K Orth, PM Jehle, A Schwarz, G Steinbach, S Schleich, C Ulmer, M Storck, A Hannekum: Enteral application of an immunoglobulin-enriched colostrum milk preparation for reducing endotoxin 
translocation and acute phase response in patients undergoing coronary bypass surgery - a randomized placebo controlled pilot trial. Wien Klin Wochenschr 114 (21-22), 923-8 (2002)

doi not found

185. JR Döhler, L Nebermann: Bovine colostrum in oral treatment of enterogenic endotoxaemia in rats. Crit Care 6 (6), 536-9 (2002)

DOI: $10.1186 /$ cc1819

186. LL Go, CT Albanese, SC Watkins, RL Simmons, MI Rowe: Breast milk protects the neonate from bacterial translocation. J Pediatr Surg 29 (8), 1059-63 (1994)

DOI: 10.1016/0022-3468(94)90279-8

187. R Lissner, H Schmidt, $H$ Karch: A standard immunoglobulin preparation produced from bovine colostra shows antibody reactivity and neutralization activity against Shiga-like toxins and EHEC-hemolysin of Escherischia coli 0157:H7. Infection 24 (5), 378-383 (1996) DOI: 10.1007/BF01716084

188. AY Kshirsagar, MA Vekariya, V Gupta, AS Pednekar, A Mahna, R Patankar, A Shaikh, B Nagur: A comparative study of colostrum dressing versus conventional dressing in deep wounds. J Clin Diagn Res 9 (4), 1-4 (2015) DOI: $10.7860 / j c d r / 2015 / 12004.5739$

189. PF Davis, NS Greenhill, AM Rowan, LM Schollum: The safety of New Zealand bovine colostrum: Nutritional and physiological evaluation in rats. Food Chem Toxicol 45 (2), 229-36 (2007)

DOI: 10.1016/j.fct.2006.07.034

190. WG Struff, G Sprotte: Bovine colostrum as a biologic in clinical medicine: a review - Part II: clinical studies. Int J Clin Pharmacol Ther 46 (5), 211-225 (2008)

DOI: 10.5414/CPP46211

191. S Tsabouri, K Douros, KN Priftis: Cow's milk allergenicity. Endocr Metab Immune Disord Drug Targets 14 (1), 16-26 (2014)

DOI: $10.2174 / 1871530314666140121144224$

Abbreviations: $B C$, bovine colostrum; $C D$, Crohn's disease; CLN, colostrinin; EGF, Epidermal growth factor; GD3, Disialoganglioside 3; GM3, Monosialoganglioside 3; GMP, glycomacropeptide; IBD, Inflammatory bowel disease; IGF-I, Insulinlike growth factors I; IGF-II, Insulin-like growth factors II; Igs, Immunoglobulins; IL-6, Interleukin-6;
Lf, Lactoferrin; MODS, multiple organ dysfunction syndrome; NEC, Necrotizing enterocolitis; NO, nitric oxide; NSAIDs, non-steroidal anti-inflammatory drugs; PDGF, Platelet-derived growth factor; ROS, reactive oxygen species; SBS, Short bowel syndrome; SIL, sporozoites inhibiting the adhesion of lipid; SIRS, systemic inflammatory response syndrome; TGF- $\alpha$, Transforming growth factor- $\alpha$; TGF- $\beta$, Transforming growth factor- $\beta$; VEGF, Vascular endothelial growth factor; UC, ulcerative colitis.

Key Words: Colostrum, Anti-Microbical Factors, Immunity, Growth Factors, Intestinal Disorders, Review

Send correspondence to: Gabriele Brecchia, Dipartimento di Medicina Veterinaria, Università degli Studi di Perugia, Via San Costanzo 4, 06126 Perugia, Italy. Tel: 390755857641, Fax: 0755857738,E-mail: gabriele.brecchia@unipg.it 